\title{
A new species of Centrorhynchus (Acanthocephala, Centrorhynchidae) endoparasite of Guira guira (Aves, Cuculidae) from Argentina
}

\author{
L. I. LUNASCHI, F. B. DRAGO
}

\begin{abstract}
Laboratorio de Helmintología, División Zoología Invertebrados. Museo de La Plata, Facultad de Ciencias Naturales y Museo, Paseo del Bosque S/No, 1900 La Plata, Buenos Aires, Argentina, E-mail: lunaschi@fcnym.unlp.edu.ar
\end{abstract}

\begin{abstract}
Summary
Centrorhynchus guira $\mathrm{n}$. sp. is described from the guira cuckoo, Guira guira (Gmelin) (Cuculiformes: Cuculidae), from Argentina. This new species is characterized by the proboscis armament with 32 longitudinal rows (29 with 18 hooks per row and 3 with 19 hooks per row) and by the following hook pattern per row: $8-9$ true hooks, 4 transitional hooks with lateral alate processes, and 6 spiniform hooks. The presence of transitional hooks is shared with five other Neotropical species in the genus: $C$. polymorphus, C. albidus, C. microcephalus, C. kuntzi and C. crotophagicola. Among these species, C. guira n. sp. most closely resembles C. kuntzi in having transitional hooks with lateral alate processes, however differs in the number of hooks per row and spiniform hooks. This is the first record of the genus Centrorhynchus parasitizing Argentinean birds. A key to the species of the Neotropical Centrorhynchus Lühe 1911 is presented.
\end{abstract}

Keywords: Centrorhynchidae; Centrorhynchus guira n. sp.; Guira guira; Cuculidae; Argentina

\section{Introduction}

The species of Centrorhynchus Lühe 1911 uses birds and mammals as definitive hosts, terrestrial arthropods as intermediate hosts, and amphibious, reptiles or insectivorous mammalians as transport or paratenic hosts. To date, of the 97 species of Centrorhynchus known worldwide, only eight have been reported in the Neotropical Region, 7 of them are endemic and one was found in the Nearctic Region (Table 1). Particularly in Argentina, where the acanthocephalan fauna is insufficiently known, adults of Centrorhynchus tumidulus (Rudolphi 1819) were reported parasitizing the intestine of didelphid marsupials (Boero \& Boehringer, 1967) and juveniles of Centrorhynchus sp. parasitizing the snakes Clelia rustica (Cope) and Leptophis ahaetulla marginatus (Cope) (Colubridae) (Vizcaíno,
1993; Lamas \& Lunaschi, 2009).

The purpose of this paper is to describe a new species of Centrorhynchus obtained from the intestine of the guira cuckoo, Guira guira (Gmelin), from Formosa province, north eastern Argentina.

\section{Materials and methods}

Mature specimens of acanthocephalans were obtained from the guira cuckoo, Guira guira, from La Marcela farm (2617'35”S; 59 06'67”W), Pirané, Formosa Province, Argentina. The birds were dissected, and the viscera were removed and examined under a stereoscopic microscope. Acanthocephalans collected alive were extended in distilled water prior to fixation, and then fixed in $5 \%$ formaldehyde, stored in $70 \%$ alcohol. Some specimens were cleared as temporary mounts in lactophenol and studied using light microscopy. Other specimens were dried using the critical point method, examined under a scanning electron microscope (Jeol 6360 LV, Tokyo, Japan) and photographed. Female specimens were dissected to analyze details of reproductive system. The number of proboscis hook rows was counted from specimens prepared for SEM. Measurements are given in millimeters $(\mathrm{mm})$, unless otherwise indicated; range is followed by the mean in parentheses. The pattern of hooks per row is expressed as the number of true hooks + number of hooks of transition + number of spiniform hooks.

The material has been deposited in the Helminthological Collection of the Museo de La Plata (MLP), Buenos Aires, Argentina.

\section{Results and Discussion}

Centrorhynchus guira n. sp. (Figs. 1-2)

Description: Based on 10 mature specimens ( 5 males and 5 females). Body elongated, filiform, with sexual dimor- 


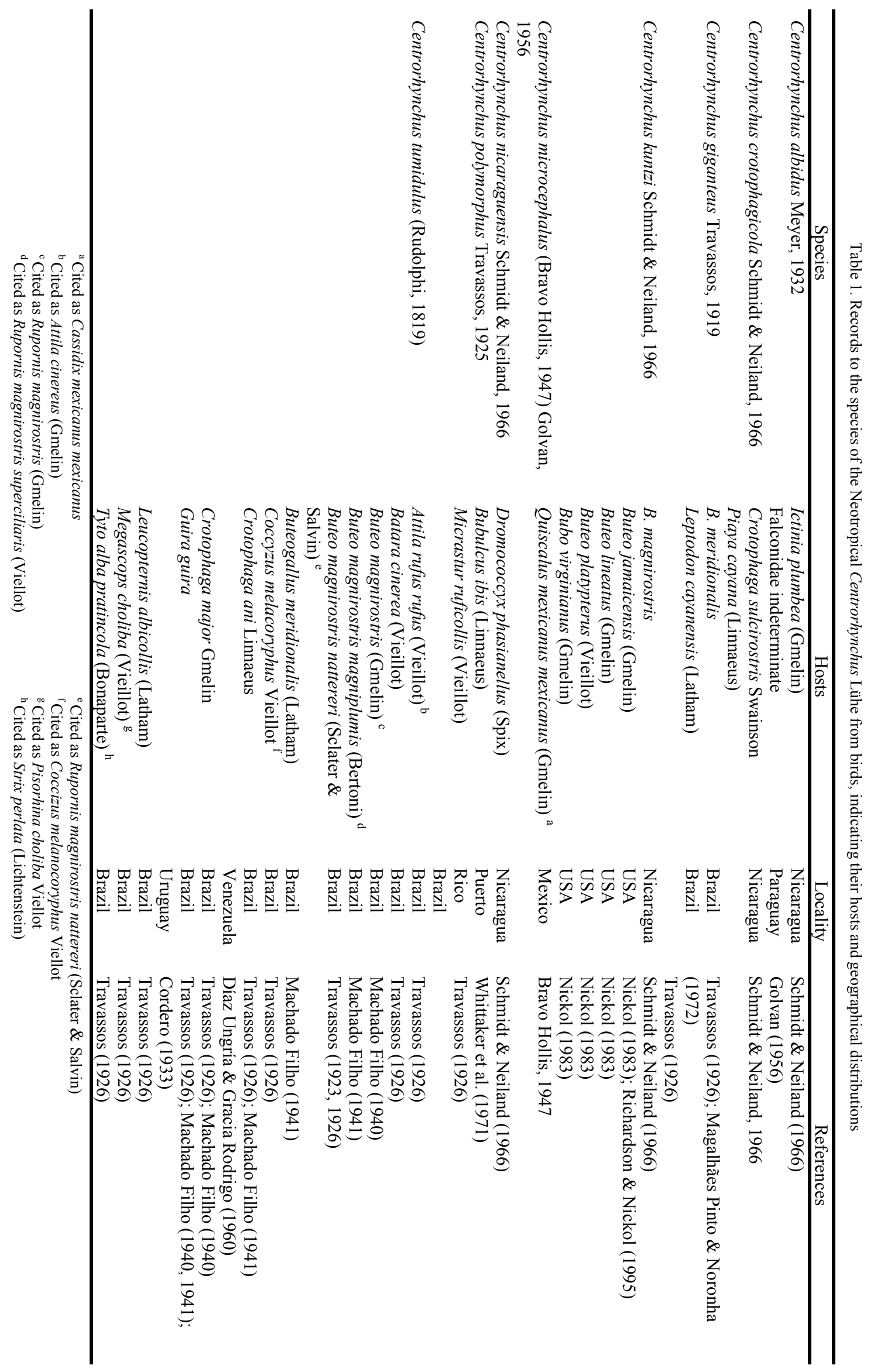



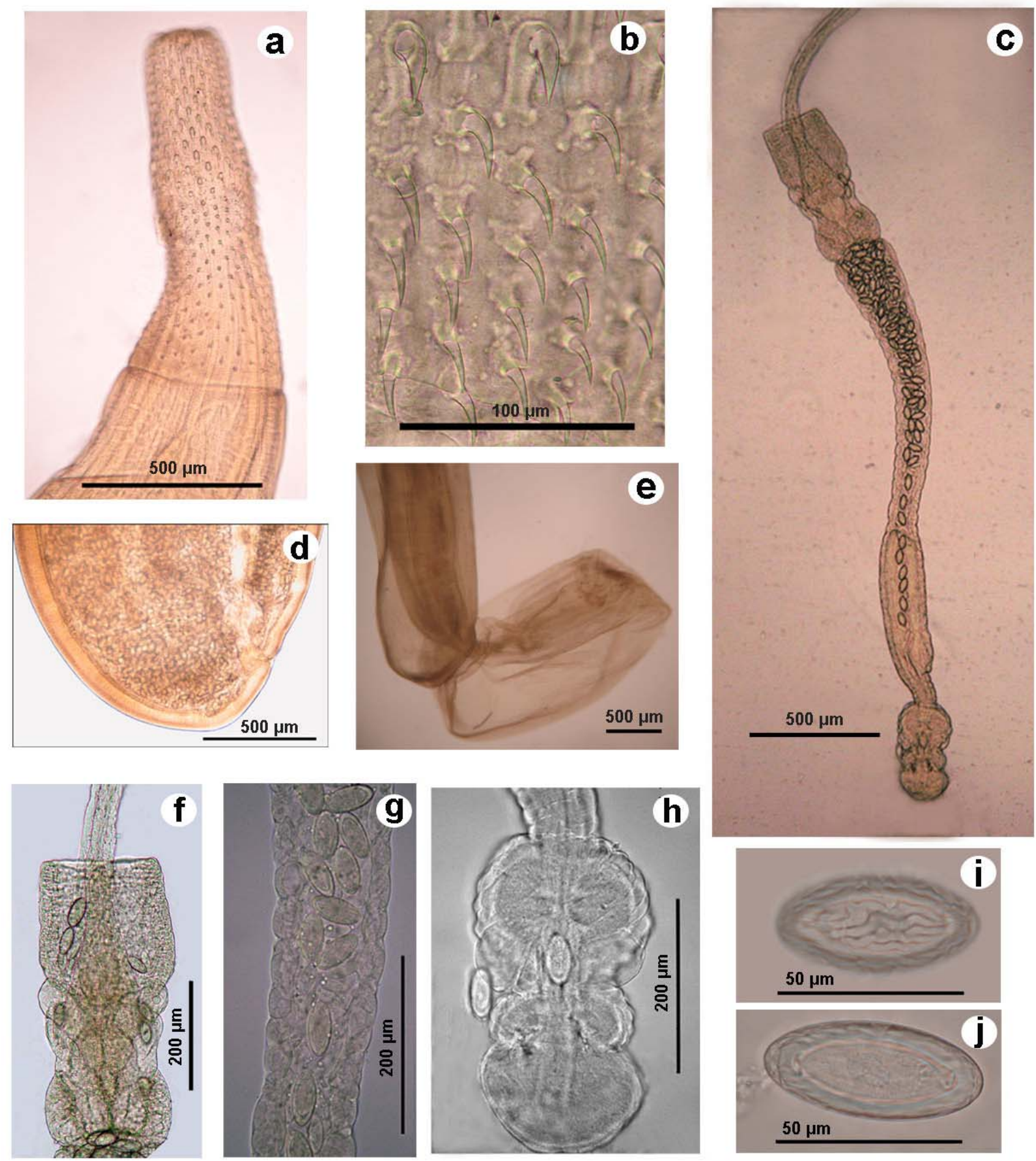

Fig. 1. Microphotographs of Centrorhynchus guira $\mathrm{n}$. sp. a - proboscis armament; b - detail of transitional hooks; $\mathbf{c}$ - female, reproductive system; d female, posterior end; $\mathbf{e}$ - male, posterior end with everted copulatory bursa; $\mathbf{f}$ - detail of uterine bell; $\mathbf{g}$ - detail of uterus; $\mathbf{h}$ - vagina showing 2 sphincters; $\mathbf{i}$ - egg, superficial view; $\mathbf{j}$ - egg, detail of acanthor and middle shell without polar prolongations. 

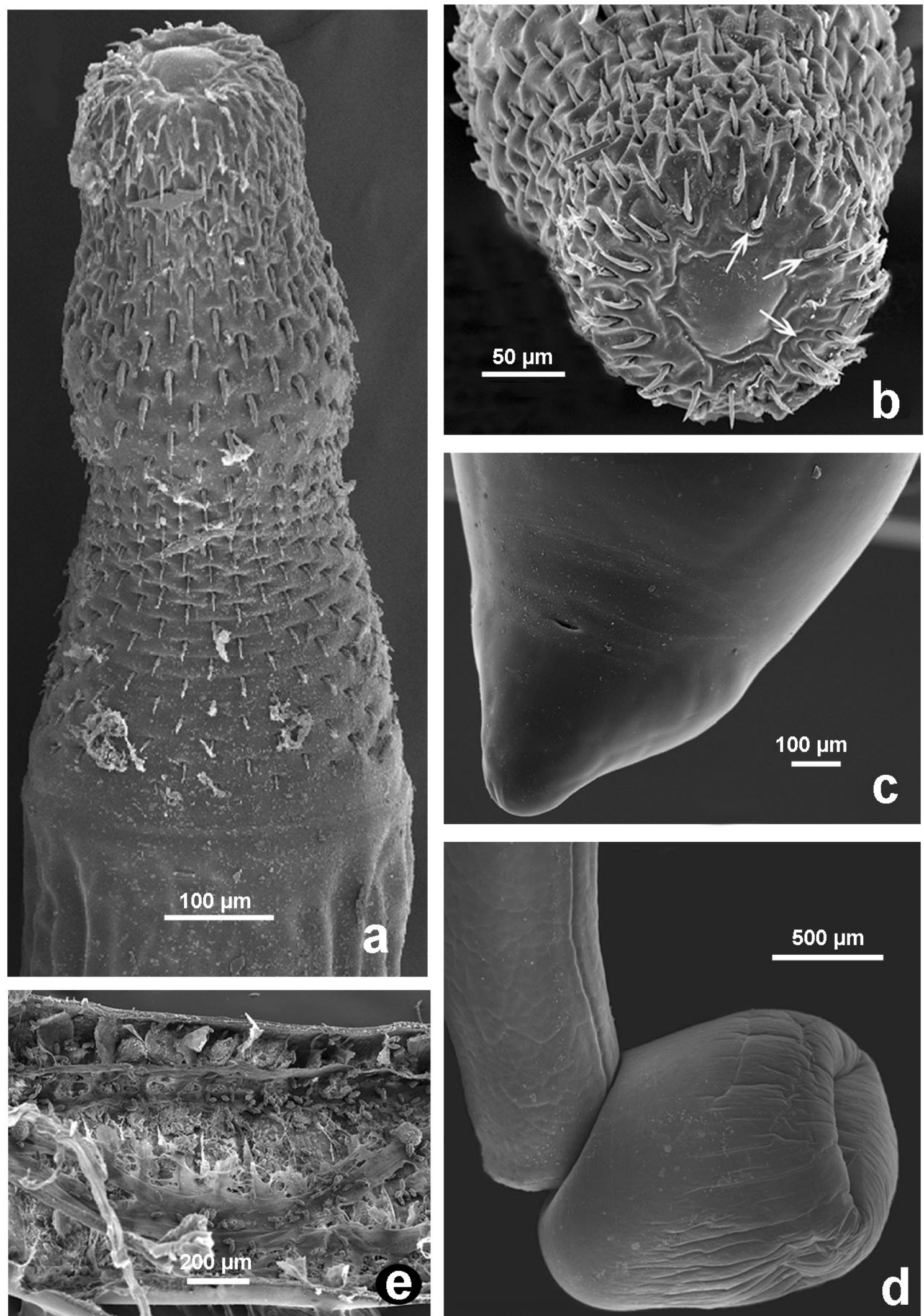

Fig. 2. SEM micrographs of Centrorhynchus guira $\mathrm{n}$. sp.: a - proboscis armament, lateral view; $\mathbf{b}$ - proboscis armament, apical view, showing longitudinal rows with 19 hooks per row (arrow); $\mathbf{c}$ - female, posterior end; $\mathbf{d}$ - male, posterior end with everted copulatory bursa; e - internal anatomy showing an apparent segmentation. 


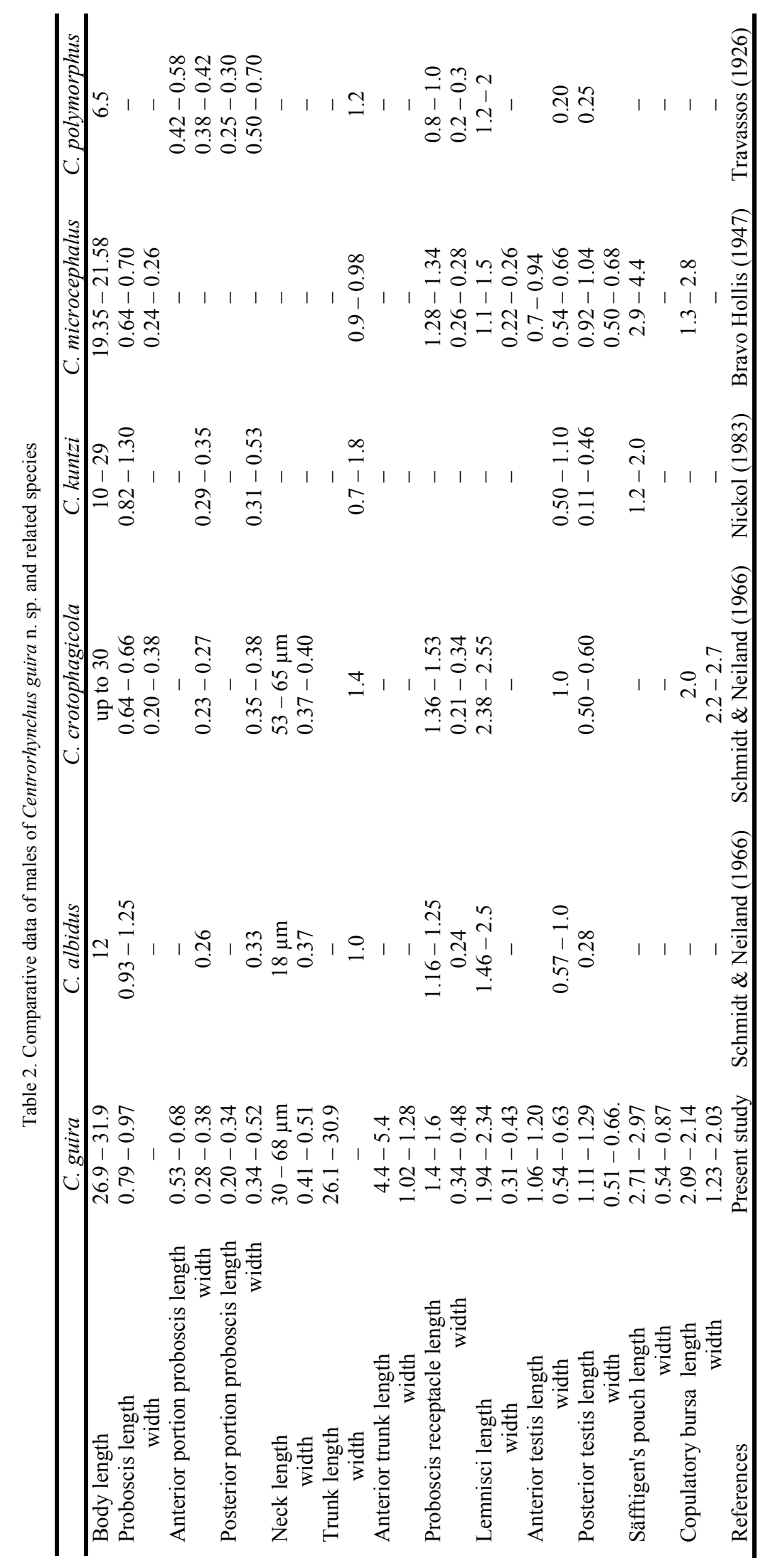


phism, females longer than males. Posterior end of females dilated and rounded. Proboscis nearly cylindrical, divided into 2 portions by constriction at level of insertion of the proboscis receptacle; anterior portion of proboscis almost cylindrical, slightly swollen at level of last true hooks; posterior portion conical. Neck short. Trunk cylindrical, with evident swelling in anterior region and internal pseudosegmentation. Proboscis receptacle with double wall. Cerebral ganglion oval, situated approximately in the middle of the proboscis receptacle. Lemnisci digitiform, longer than proboscis receptacle. Proboscis armament consists of 32 longitudinal rows; 29 longitudinal rows with 18 hooks per row and 3 longitudinal rows with 19 hooks per row. First $8-9$ true hooks, longer, with posteriorly directed roots, swollen at base; in alternating rows, the last true hooks are smaller; next 4 hooks transitional with roots directed anteriorly (the first with 4 lateral alate-processes and the last with slender root swollen at base); remaining 6 hooks on posterior portion of proboscis, spiniform. Pattern of hooks per row: $8-9+4+6$.

Male. Body $26.9-31.9$ (28.8) in total length. Proboscis $0.79-0.97$ (0.86) long; anterior portion elongated $0.53-$ $0.68(0.59)$ long, $0.28-0.38(0.31)$ wide; posterior portion $0.20-0.34(0.27)$ long, $0.34-0.52(0.40)$ wide. First 7 true hooks: blade $38-48$ (41) $\mu \mathrm{m}$ long, root $45-60$ (49) $\mu \mathrm{m}$ long; last true hook: blade $24-31$ (27) $\mu \mathrm{m}$ long, root 21 - 36 (29) $\mu \mathrm{m}$ long; transitional hooks: blade $19-33$ (26) $\mu \mathrm{m}$ long, root $17-21$ (20) $\mu \mathrm{m}$ long; spiniform hooks: $14-26$ (21) $\mu \mathrm{m}$ long. Neck $30-68$ (47) $\mu \mathrm{m}$ long, $411-$ 513 (460) $\mu \mathrm{m}$ wide. Trunk 26.1 - 30.9 (27.9) long; anterior trunk widened $4.4-5.4$ long, $1.02-1.28$ wide, separated from remainder trunk by a constriction. Proboscis receptacle, $1.4-1.6$ (1.5) long, $0.34-0.48(0.41)$ wide. Lemnisci $1.94-2.34$ (2.14) long, $0.31-0.43$ (0.39) wide. Testes oval, located in tandem, contiguous or slightly overlapping one another in anterior part of trunk; anterior testis $1.06-$ 1.20 (1.14) long, $0.54-0.63$ (0.59) wide, situated at $0.94-$ 1.54 (1.22) from proboscis receptacle; posterior testis $1.1-$ 1.29 (1.20) long, $0.51-0.66$ (0.60) wide. Cement glands 3, tubular, situated immediately posterior to hind testis. Säfftigen's pouch conspicuous, $2.71-2.97$ (2.88) long, $0.54-0.87(0.75)$ wide. Genital pore terminal. Copulatory bursa, rounded or cylindrical when fully everted, $2.09-$ 2.14 (2.11) long, 1.23 - 2.03 (1.63) wide.

Female. Body $38.8-50.4$ (43.6) in total length. Proboscis 0.92 - 1.0 (0.95) long; anterior portion $0.48-0.69(0.60)$ long, $0.34-0.48(0.39)$ wide; posterior portion $0.31-0.43$ (0.35) long, $0.44-0.49(0.47)$ wide. First 7 true hooks: 40 - 48 (43) $\mu \mathrm{m}$ long, root 36 - 64 (49) $\mu \mathrm{m}$ long; last true hook: blade $31-36$ (34) $\mu \mathrm{m}$ long, root $36-45$ (40) $\mu \mathrm{m}$ long; transitional hooks: blade $21-29$ (26) $\mu \mathrm{m}$ long, root $14-26$ (19) $\mu \mathrm{m}$ long; spiniform hooks: $17-28$ (22) $\mu \mathrm{m}$ long. Neck $39-68$ (54) $\mu \mathrm{m}$ long, 478 - 522 (506) $\mu \mathrm{m}$ wide. Trunk 37.8 - 49.4 (42.6) long; anterior trunk widened 5.57 - 5.88 (5.70) long; 1.10 - 1.43 (1.26) wide, separated from remainder trunk by a constriction. Proboscis receptacle $1.69-1.77$ (1.73) long, $0.37-0.46(0.42)$ wide.
Lemnisci 1.8 - 2.71 (2.43) long, $0.24-0.39$ (0.29) wide. Female genital tract (measured from opening of uterine bell to genital pore in one dissected specimen) 2.63 in length from opening of uterine bell to genital pore; uterine bell 0.34 long, 0.25 wide; uterus 1.7 ; vagina 0.34 long, provided with 2 sphincters. Genital pore ventral, subterminal, at $0.29-0.53(0.44)$ from tip posterior end. Eggs elongated, without polar prolongations and with outer shell corrugated, $53-63 \times 24-29(57 \times 27) \mu \mathrm{m}$.

Type host: Guira guira (Gmelin) (guira cuckoo) (Cuculiformes: Cuculidae)

Site of infection: intestine.

Type locality: La Marcela farm (26 $17^{\circ} 35^{\prime \prime}$; 5906'67'W), Pirané, Formosa Province, Argentina.

Specimens deposited: MLP No 5945 (holotype male); $\mathrm{N}^{\mathrm{o}}$ 5946 (allotype female); No 5947 - 5950 (paratypes)

Etymology: The new species is named after the specific name of the host.

\section{Remarks}

According to Golvan (1956), in the species of the genus Centrorhynchus the number of longitudinal rows, number of hooks per row, size of the blades and morphology and size of roots are the characteristics with greater taxonomic value. Golvan (1960) described three types of hooks in this genus: true, spiniform and transitional. These last hooks are characterized by having roots directed anteriorly and lateral alate processes, and can be absent in some species. The presence of transitional hooks readily distinguishes the specimens obtained from G. guira from most of the Neotropical species of Centrorhynchus. At present, five species have been reported with transitional hooks: Centrorhynchus polymorphus Travassos 1925, Centrorhynchus albidus Meyer 1932, Centrorhynchus microcephalus (Bravo Hollis 1947) Golvan 1956, Centrorhynchus kuntzi Schmidt \& Neiland 1966, Centrorhynchus crotophagicola Schmidt \& Neiland 1966. Among these species, C. kuntzi is the most similar species to $C$. guira n. sp., by having transitional hooks with lateral alate processes as describe Golvan (1960), and the first of them with 4 alate processes. However, this species differs mainly in the number of hooks per row $(22-27$ versus $18-19)$ and spiniform hooks (14 - 18 versus 6), and by possessing a digitiform papilla at posterior end (Schmidt \& Neiland, 1966; Nickol, 1983). In addition, the measurements of body, testes, Säfftigen's pouch and eggs are smaller than $C$. guira n. sp. (Table 2, 3).

The remaining species differ mainly from the new species in having transitional hooks without lateral alate processes. The proboscis armature of $C$. albidus differs from that observed in the new species by having a lesser number of longitudinal rows $(28-30)$, a greater number of hooks per row $(20-22)$, and a different pattern of hooks per row $(8+$ $4+10$ ) (Schmidt \& Neiland, 1966; Fig. 5). The females differ by having smaller body and eggs, whereas the males differ in the size of body and testes (Table 2, 3). The proboscis armature of $C$. crotophagicola is similar to $C$. guira 


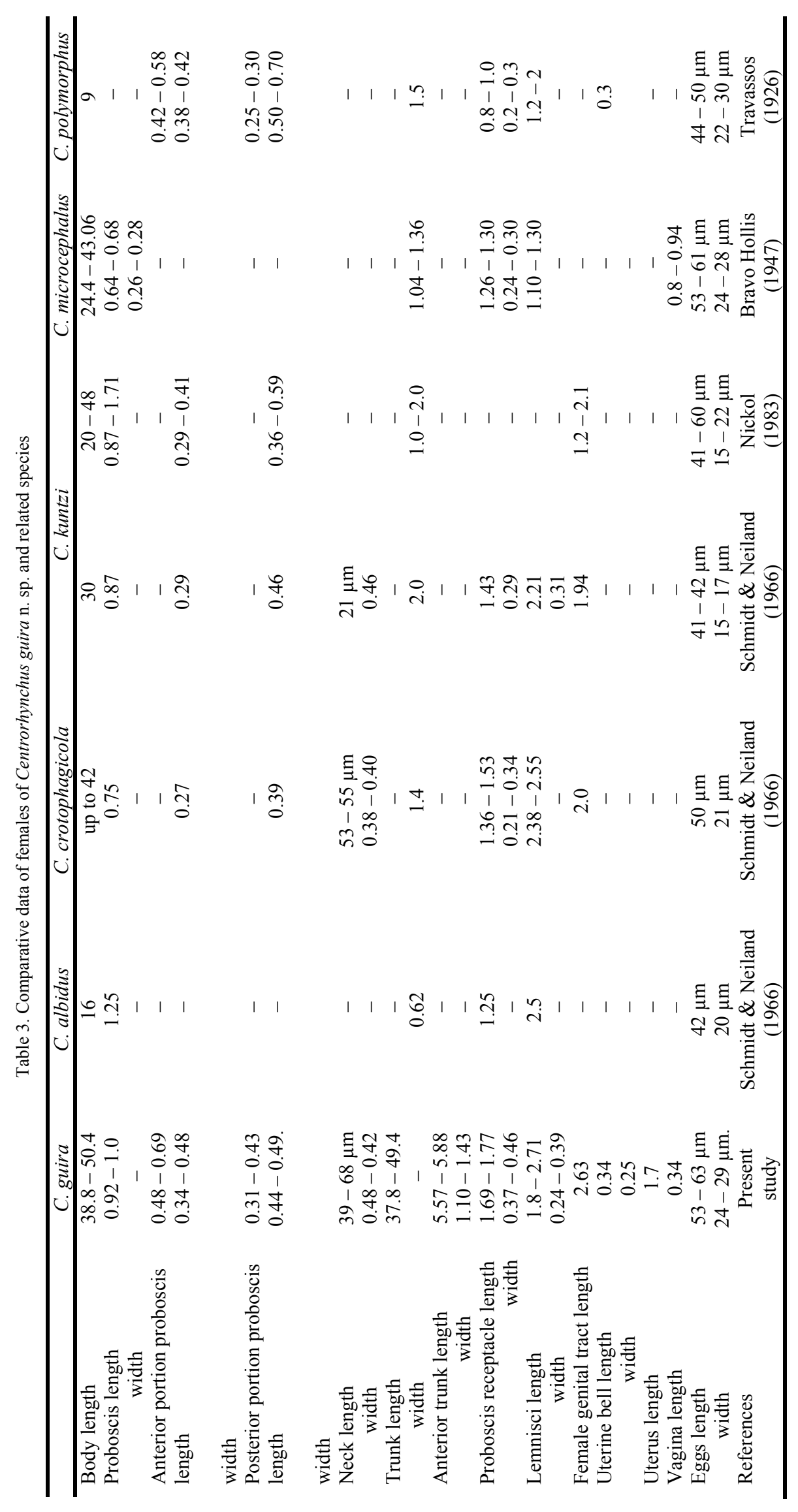




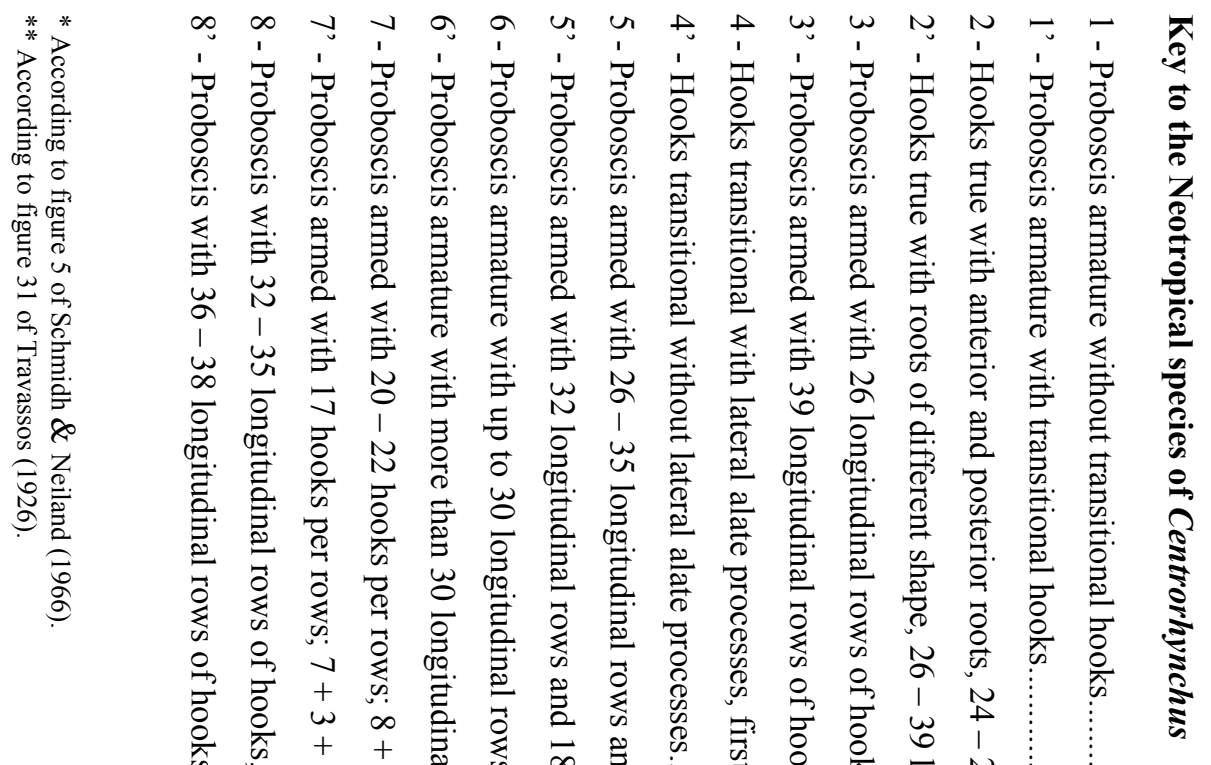

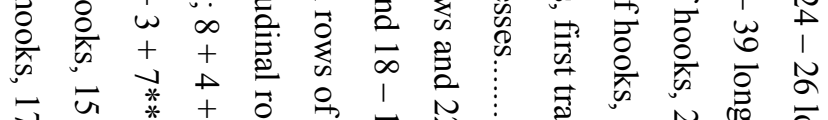

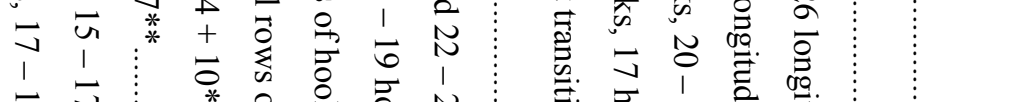

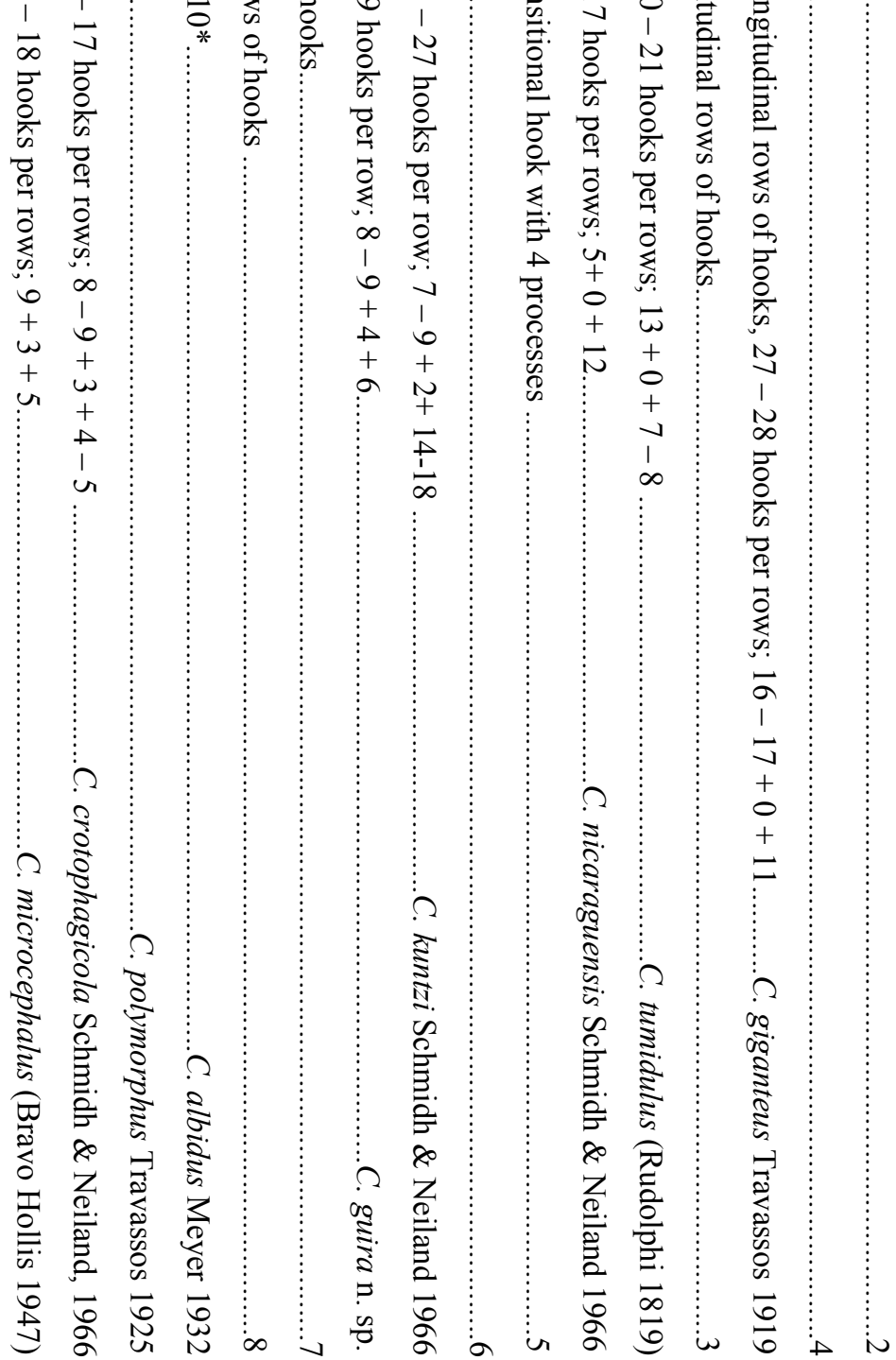


n. sp. in the number of longitudinal rows of hooks. (3235). Schmidt and Neiland (1966) characterized this species by the presence of $15-17$ hooks per rows, of which the first $8-9$ in each row have well-developed roots, being the remaining hooks rootless but with strong anteriorly directed manubrium, without detailing the presence of transitional hooks. Later, Dimitrova and Gibson (2005) described encysted juveniles of this species from Anolis lineatopus lineatopus Grey and A. sagrei Duméril \&Bibron from Jamaica and reported new data for the pattern of hooks per row: $8-9+3+4-5$ (exceptionally 6 ). The most important morphological differences between the proboscis armature of the new species and $C$. crotophagicola, are the greater number of hooks per longitudinal row (18 versus $15-17)$ and the greater number of transitional hooks (4 versus 3). Moreover, the females differ by having a terminal papilla at posterior end, smaller proboscis, proboscis receptacle and eggs than $C$. guira n. sp. (Table 2, 3). The armature proboscis of $C$. microcephalus differs mainly from that observed in $C$. guira by having a greater number of longitudinal rows $(36-38)$ and the following pattern of hooks: $9+3+5$ (see Bravo Hollis, 1947; Fig. 2). The males differ by having smaller body, lemnisci and proboscis, whereas the females differ by having a smaller proboscis, proboscis receptacle and lemnisci (Table 2, 3). Finally, C. polymorphus differs from the new species in the pattern of hooks per row $(7+3+7)$, by having a lesser number of longitudinal rows (30) and hooks per row (17), and by having smaller body, proboscis, proboscis receptacle, lemnisci and testes (Table 2, 3). On the other hand, the taxonomic position of this species is controverted since Golvan (1956) include it in the subgenus Longirostris, as $C$. (Longirostris) polymorphus; posteriorly, Golvan (1960) and Yamaguti (1963) consider it as C. polymorphus and Dimitrova and Gibson (2005) believe that this species better fits Sphaerirostris Golvan 1956 than Centrorhynchus due to the shape and size of the body and proboscis.

\section{Acknowledgements}

Special thanks are due to Dr. Carlos Montoya for help and hospitality during our stay in Formosa Province. The authors, Lía Lunaschi and Fabiana Drago are members of the Comisión de Investigaciones Científicas de la Provincia de Buenos Aires (CIC) and Universidad Nacional de La Plata (UNLP), respectively. This study was funded by Comisión de Investigaciones Científicas de la provincia de Buenos Aires (CIC) (Res. No 578/08).

\section{References}

Boero, J. J., Boehringer I. K. (1967): El Parasitismo de nuestra fauna autóctona. Rev. Fac. C. Vet., La Plata, 9(21): $147-160$

BRAVO Hollis, M. (1947): Gordiorhynchus microcephalus n. sp. acantocéfalo parásito de un pájaro (Cassidix mexicanus mexicanus). An. Inst. Biol. Méx., 18(2): 499 - 506 Cordero, E. H. (1933): Sur quelques acanthocéphales de
l'América méridionale. I. Ann. Parasitol. Hum. Comp., 11(4): $271-279$

DíAZ Ungría, C., Gracia Rodrigo, A. (1960): Nueva aportación al conocimiento de los acantocéfalos venezolanos. Rev. Vet. Venez., 8(46): $279-283$

Dimitrova, Z. M., GiBSON, D. I. (2005): Some species of Centrorhynchus Lühe, 1911 (Acanthocephala: Centrorhynchidae) from the collection of the Natural History Museum, London. Syst. Parasitol., 62:117 - 134. DOI: 10.1007/s11230-005-5486-7

Golvan, Y. J. (1956): Le genre Centrorhynchus Lühe, 1911 (Acanthocephala-Polymorphidae). Révision des espèces européennes et description d'une nouvelle espèce africaine parasite de rapace diurne. Bull. Inst. Fond. Afr. Noire, 18(3): $732-785$

Golvan, Y. J. (1960): Le Phylum des Acanthocephala. Troisième note. La Classe des Palaeacanthocephala (Meyer, 1931) (suite). Ann. Parasitol. Hum. Comp., 35(4): $575-593$

HARTwich, G. H. (1956): Südamerikanische Acanthocephalen aus der Zoologischen Sammlung des Bayerischen Staates. Zool. Anz. 156(11 - 12): 299 - 308.

LAMAS, M. F., LunASCHI, L. I. (2009): Ocurrencia de Centrorhynchus sp. (Acantohocephala: Centrorhynchidae) en Leptophis ahaetulla marginatus (Squamata: Colubridae). Cuad. herpetol., 23(1): 45 - 49

MaCHADO FILHO, D. A. (1940): Pesquisas helmintológicas realizadas no Estado de Mato Grosso. Acanthocephala. Mem. Inst. Oswaldo Cruz, 35(3): 391 - 407

Machado FilHo, D. A. (1941): Sobre alguns acantocéfalos provenientes do Estado de Mato Grosso. Rev. Bras. Biol., 1(1): $57-61$

Magalhães Pinto, R., Noronha, D. (1972): Contribuição ao conhecimento da fauna helmintológica do Município de Alfenas, Estado de Minas Gerais. Mem. Inst. Oswaldo Cruz, 70(3): 391 - 407

NicKOL, B. B. (1983): Centrorhynchus kuntzi from the USA with description of the male and redescription of $C$. spinosus (Acanthocephala: Centrorhynchidae). J. Parasitol., 69(1): $221-225$

Richardson, D. J., NiCKOL, B. B. (1995): The genus Centrorhynchus (Acanthocephala) in North America with description of Centrorhynchus robustus n. sp., redescription of Centrorhynchus conspectus, and a key to species. $J$. Parasitol., 81(5): $767-762$

SchMIDT, G. D., NeILAND, K. A. (1966): Helminth fauna of Nicaragua. III. Some acantocephala of birds, including three new species of Centrorhynchus. J Parasitol., 52(4): $739-745$

Travassos, L. (1923): Informações sobre a fauna helminthologica de Matto Grosso (II nota). Folha Med., 4: $1-5$

TRAVASSOS, L. (1926): Contribuições para o conhecimento da fauna helminthologica brasileira. XX. Mem. Inst. Oswaldo Cruz, 19(1): 31 - 125

VizCAINO, S. I. (1993): Presencia del género Centrorhynchus Lühe, 1911, (Acanthocephala: Centrorhynchidae) en la República Argentina. Neotropica, 39(101-102): 77 - 78 
Whittaker, F. H., Schmidt, G. D., Diaz, J. G. (1971): Helminth parasites of the cattle egret in Puerto Rico. Proc. Helm. Soc. Wash.., 38(2): 262

ACCEPTED NOVEMBER 11, 2009
Yamaguti, S. (1963): Systema Helminthum. Vol. 5. Acanthocephala. Wiley Interscience, New York and London, 423 pp.

RECEIVED JUNE 22, 2009 